Intisari Sains Medis 2019, Volume 10, Number 1: 169-173

P-ISSN: 2503-3638, E-ISSN: 2089-9084

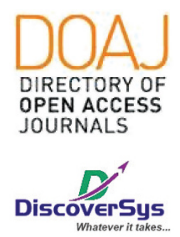

Published by DiscoverSys

\section{Perbedaan kadar antitrombin III pada sepsis neonatal kultur darah positif dan kultur darah negatif}

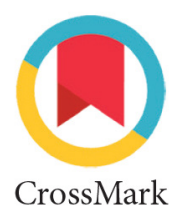

CrossMark

\author{
Prima Indah Siridian ${ }^{1 *}$, Ricke Loesnihari ${ }^{1}$, Guslihan Dasa Tjipta ${ }^{2}$
}

\section{ABSTRACT}

Background: Fetal and neonatal hemostatic systems are dynamic. Coagulation and inhibitors of coagulation factors are progressively synthesized by the fetus which begins after 34 weeks of pregnancy and at the initial hours after birth. The neonatal hemostatic system generally shifts towards hypercoagulability. During sepsis, this hypercoagulability is exacerbated by an imbalance of coagulation and inhibitors of coagulation factors including antithrombin III. This study aimed to determine differences of antithrombin III levels in neonatal sepsis positive blood cultures (proven sepsis) and negative blood cultures (unproven sepsis).

Methods: The subjects of this study were 26 patients of neonatal sepsis, which consisted of 13 positive blood cultures and 13 negative blood cultures. Levels of antithrombin III were examined by chromogenic methods. Examination of blood cultures of grampositive bacteria using manual method and gram-negative bacteria using semiautomatic method. Data analysis uses an independent t test.

Results: Antithrombin III levels in neonatal sepsis patients positive blood culture $(73,23 \pm 21,62)$ didn't differ significantly compared to negative blood cultures $(65,63 \pm 20,81)$ with $p=0,370$ ( $p>$ $0,05)$. The bacterial pattern that caused neonatal sepsis were Staphylococcus sp. $(84,6 \%)$, CoNS $(81,8 \%)$, Staphylococcus aureus $(18,2 \%)\}$, Salmonella spp $(7,7 \%)$ and Klebsiella pneumoniae ssp pneumoniae $(7,7 \%)$. The sensitivity pattern of Staphylococci to cefoxitin to determine resistence, found 5 Methicillin-resistant Staphylococci (MRS) and 1 Meticillin-resistant Staphylococcus aureus (MRSA).

Conclusion: There were no significant differences of antithrombin III levels in neonatal sepsis positive blood cultures and negative blood cultures.
'Departemen Patologi Klinik, Fakultas Kedokteran Universitas Sumatera Utara/RSUP Haji Adam Malik, Medan, Indonesia 2Departemen IImu Kesehatan Anak, Fakultas Kedokteran Universitas Sumatera Utara/ RSUP Haji Adam Malik, Medan, Indonesia

Keywords: Antithrombin III, Neonatal Sepsis, Positive Blood Culture, Negative Blood Culture

Cite This Article: Siridian, P.I., Loesnihari, R., Tjipta, G.D. 2019. Perbedaan kadar antitrombin III pada sepsis neonatal kultur darah positif dan kultur darah negatif. Intisari Sains Medis 10 (1): 169-173. D0I: 10.1556/ism.v10i1.335

\title{
ABSTRAK
}

Latar belakang: Sistem hemostatis janin dan neonatus bersifat dinamis. Koagulasi dan inhibitor faktor koagulasi secara progresif disintesis oleh janin yang dimulai sejak 34 minggu kehamilan dan jam-jam awal setelah dilahirkan. Sistem hemostatis neonatus umumnya bergeser ke arah hiperkoagulabititas. Selama sepsis, hiperkoagulabilitas ini diperburuk dengan adanya ketidakseimbangan koagulasi dan inhibitor faktor koagulasi termasuk antitrombin III. Tujuan penelitian ini untuk mengetahui perbedaan kadar antitrombin III pada sepsis neonatal kultur darah positif (proven sepsis) dan kultur darah negatif (unproven sepsis).

Metode: Subyek penelitian ini adalah 26 pasien sepsis neonatal, yang terdiri dari 13 kultur darah positif dan 13 kultur darah negatif. Kadar antitrombin III diperiksa dengan metode kromogenik. Pemeriksaan kultur darah bakteri Gram positif dilakukan dengan metode manual dan bakteri Gram negatif dengan metode semiautomatik. Analisis data menggunakan uji-t independent. Hasil: Pola kuman penyebab sepsis neonatal adalah Staphylococcus sp. $(84,6 \%)$, Coagulase-negative Staphylococci (CoNS) (81,8\%), Staphylococcus aureus $(18,2 \%)\}$, Salmonella spp $(7,7 \%)$ dan Klebsiella pneumoniae ssp pneumoniae (7,7\%). Pola sensitivitas bakteri Staphylococci terhadap (efoxitin untuk melihat resistensi didapatkan 5 Methicillin-resistant Staphylococci (MRS) dan 1 Meticillin-resistant Staphylococcus aureus (MRSA). Kadar antitrombin III pada pasien sepsis neonatal kultur darah positif $(73,23 \pm 21,62)$ tidak berbeda secara signifikan dibandingkan dengan kultur darah negatif $(65,63 \pm 20,81)$ dengan nilai $p=0,370$ $(p>0,05)$.

Kesimpulan: Tidak terdapat perbedaan yang signifikan kadar antitrombin III pada pasien sepsis neonatal kultur darah positif dan kultur darah negatif.

Kata kunci: Antitrombin III, Kultur darah negatif, Kultur darah positif, Sepsis neonatal

Cite Pasal ini: Siridian, P.I., Loesnihari, R., Tjipta, G.D. 2019. Perbedaan kadar antitrombin III pada sepsis neonatal kultur darah positif dan kultur darah negatif. Intisari Sains Medis 10 (1): 169-173. D0I: 10.1556/ism.v10i1.335 


\section{PENDAHULUAN}

Sepsis neonatal merupakan suatu sindrom penyakit sistemik disertai bakteremia yang terjadi pada satu bulan pertama kehidupan. ${ }^{1}$ Sepsis menyebabkan morbiditas dan mortalitas yang tinggi dengan angka kejadian keseluruhan sepsis neonatal primer adalah 1-5 per 1.000 kelahiran hidup. Angka kematian sepsis neonatal cukup tinggi yaitu sebesar 13-25\%, dengan angka yang lebih tinggi pada neonatus prematur dan pada neonatus dengan penyakit fulminan dini. ${ }^{2}$

Diagnosis sepsis neonatal sering sulit ditegakkan karena gejala klinis yang tidak spesifik. Oleh karena itu dibutuhkan pemeriksaan penunjang biakan (kultur) darah yang merupakan baku emas dalam menegakkan diagnosis sepsis serta untuk membantu mengetahui etiologinya. Namun, pemeriksaan tersebut hasilnya baru dapat diketahui setelah 48-72 jam dan sering memberikan hasil yang kurang memuaskan. ${ }^{3}$ Berdasarkan data dari unit Perawatan Neonatus Rumah Sakit Umum Pusat H. Adam Malik Medan periode bulan Januari 2008-Desember 2010 terdapat 239 neonatus dengan sangkaan sepsis. Setelah dilakukan kultur darah, dijumpai pertumbuhan bakteri hanya pada 158 spesimen. ${ }^{4}$

Sepsis memberikan dampak negatif terhadap berbagai sistem tubuh termasuk sistem hemostasis. Sistem hemostatis janin dan neonatus bersifat dinamis dengan faktor koagulasi dan inhibitornya secara progresif disintesis oleh janin yang dimulai terutama setelah 34 minggu kehamilan dan jamjam awal setelah dilahirkan. Pada keadaan normal, akan dihasilkan keseimbangan hemostatis yang relative cukup saat kelahiran. ${ }^{5}$ Sistem hemostatis neonatus dan neonatus prematur umumnya cenderung bergeser ke arah hiperkoagulabititas. Selama sepsis, hiperkoagulabilitas ini diperburuk lagi dengan adanya ketidakseimbangan koagulasi dan inhibitor faktor koagulasi termasuk protein C, protein S, dan antitrombin III. ${ }^{5}$

Antitrombin III (AT III) adalah glikoprotein dengan berat molekul $58 \mathrm{kD}$ yang berfungsi sebagai antikoagulan alamiah kuat dan diperkirakan menghambat $80 \%$ aktivitas trombin serta merupakan serine protease inhibitor (serpin) yang menginaktivasi beberapa enzim pada kaskade koagulasi, dengan target utamanya adalah trombin dan faktor Xa. ${ }^{6}$ Antikoagulan endogen ini cepat habis pada fase awal sepsis. ${ }^{7}$ Pada sepsis, kadar antitrombin III berkurang karena beberapa alasan. Ketika protein fase akut diregulasi, ada penurunan regulasi produksi antitrombin III. Penurunan lebih lanjut terjadi sebagai akibat dari peningkatan turnover plasma. Defisiensi antitrombin III merupakan konsekuensi yang dapat diprediksi pada sepsis, dan derajat defisiensi berkorelasi dengan tingkat keparahan penyakit dan hasil klinis. ${ }^{8}$

Penelitian Beshlawy dkk (2010) menunjukkan penurunan yang signifikan pada AT III, protein C, dan protein S pada 100\% kasus neonatus septik, dibandingkan dengan kelompok kontrol $\left(\mathrm{p}<\right.$ 0.001). ${ }^{5}$ Penelitian Muntaha dkk (2016) menunjukkan pada kelompok neonatus sepsis dengan prognostik buruk, kadar AT III menurun secara signifikan. ${ }^{9}$ Penelitian Ersoy dkk (2007) menyimpulkan kadar AT III awal yang menurun pada sepsis neonatal dikaitkan dengan penyakit berat dan peningkatan angka kematian yang dapat berguna dalam memprediksi hasil klinis pada sepsis neonatal. ${ }^{7}$

Tujuan penelitian ini adalah untuk mengetahui pola bakteriologis dan perbedaan kadar antitrombin III pada sepsis neonatal kultur darah positif (proven sepsis) dan kultur darah negatif (unproven sepsis).

\section{METODE}

Penelitian ini merupakan studi analitik potong lintang dan dilakukan di Departemen Patologi Klinik FK-USU/RSUP H. Adam Malik Medan. Subjek penelitian ini adalah neonatus dengan diagnosis sepsis neonatal yang ditegakkan oleh Departemen Ilmu Kesehatan Anak FK-USU/RSUP H. Adam Malik Medan dan dilakukan pemeriksaan kultur darah, yang dirawat di unit Perinatologi RSUP H. Adam Malik Medan pada bulan MaretAgustus 2018.

Penelitian ini diikuti oleh 26 neonatus sepsis, yang terdiri atas 13 neonatus dengan hasil kultur darah positif dan 13 neonatus dengan hasil kultur darah negatif yang memenuhi kriteria inklusi dan eksklusi. Neonatus yang lahir sebelum usia gestasi 34 minggu, neonatus dengan kelainan hati dan neonatus sepsis dengan DIC score $\geq 5$ dieksklusi. Dalam pengambilan sampel, setelah didapatkan 13 hasil kultur darah negatif yang sesuai dengan kriteria inklusi dan eksklusi, maka pengambilan sampel hasil kultur darah negatif dihentikan.

Pemeriksaan kadar aktivitas antitrombin III dilakukan dengan metode kromogenik menggunakan alat coagulation analyzer Coatron A4 dengan reagen TEChrom AT (anti-Xa). Nilai referensi kadar AT III pada neonatus berdasarkan umur : 0-5 hari (39-87\%), 5 hari-1 bulan (4193\%), $1-3$ bulan $(48-108 \%){ }^{10}$

Identifikasi bakteri Gram positif dilakukan secara manual dengan tes katalase, tes koagulase dan tes manitol salt agar (MSA). Identifikasi bakteri Gram negatif dilakukan secara semiautomatik dengan API 20E (Biomerieux ${ }^{R}$ SA FRANCE). Tes kepekaan terhadap antibiotik dilakukan dengan metode difusi cakram (disk diffusion method) pada 
agar Muller-Hinton yang telah diinokulasi bakteri, dengan hasil interpretasinya adalah sensitif, resisten dan intermediate.

Penelitian ini dilakukan setelah mendapat persetujuan dari komite Penelitian Bidang Kesehatan Fakultas Kedokteran Universitas Sumatera Utara Medan. Seluruh pasien neonatus yang bersedia mengikuti penelitian ini memberikan informed consent secara tertulis dari orang tua atau diwakili oleh pihak keluarga. Analisis data dilakukan dengan menggunakan software SPSS (Statistical Package for Social Sciences, Chicago, IL, USA) untuk Windows. Bila data berdistribusi normal digunakan uji t independent dan bila data tidak berdistribusi normal digunakan uji MannWhitney. Hasil penelitian dianggap signifikan bila nilai $\mathrm{p}<0,05$.

\section{HASIL}

Pada penelitian ini, karakteristik umum 26 pasien sepsis neonatal didapatkan rerata umur 9,88 $\pm 11,1$ hari dengan 17 laki-laki $(65,4 \%)$ dan 9 perempuan $(34,6 \%)$. Berdasarkan jenis kelamin, dari 13 pasien

Tabel 1. Karakteristik Umum Pasien Sepsis Neonatal

\begin{tabular}{lccc}
\hline \multirow{2}{*}{ Karakteristik } & \multicolumn{2}{c}{ Sepsis Neonatal } & Rerata/ \\
\cline { 2 - 3 } & $\begin{array}{c}\text { Kultur Darah Positif } \\
(\mathbf{n}=\mathbf{1 3})\end{array}$ & $\begin{array}{c}\text { Kultur Darah Negatif } \\
(\mathbf{n = 1 3 )}\end{array}$ & $\begin{array}{c}\text { Rerata } \\
\text { Umur }\end{array}$ \\
$\begin{array}{l}\text { Jenis Kelamin } \\
\text { Laki-laki }\end{array}$ & $9(69,2)$ & & $9,88 \pm 11,1$ \\
$\quad$ Perempuan & $4(30,8)$ & $8(61,5)$ & $17(65,4 \%)$ \\
\hline
\end{tabular}

Tabel 2. Bakteri Penyebab Kultur Darah Positif pada Sepsis Neonatal

\begin{tabular}{lcc}
\hline \multicolumn{1}{c}{ Bakteri } & N & $\%$ \\
\hline Gram Positif & 7 & \\
$\quad$ Staphylococcus epidermidis & 2 & 15,8 \\
$\quad$ Staphylococcus hemolyticus & 2 & 15,4 \\
$\quad$ Staphylococcus aureus & & \\
Gram Negatif & 1 & 7,7 \\
$\quad$ Salmonella spp & 1 & 7,7 \\
$\quad$ Klebsiella pneumoniae ssp pneumonia & 13 & 100 \\
\hline \multicolumn{1}{c}{ Total }
\end{tabular}

Tabel 3. Pola Sensitivitas Bakteri Staphylococci terhadap Cefoxitin

\begin{tabular}{lccc}
\hline \multirow{2}{*}{ Spesies Staphylococci } & \multicolumn{2}{c}{ Cefoxitin } & \multirow{2}{*}{ Total } \\
\cline { 2 - 3 } & Sensitif & Resisten & \\
\hline Staphylococcus epidermidis & 4 & 3 & 7 \\
Staphylococcus hemolyticus & 0 & 2 & 2 \\
Staphylococcus aureus & 1 & 1 & 2 \\
\hline \multicolumn{1}{c}{ Total } & 5 & 6 & 11 \\
\hline
\end{tabular}

sepsis neonatal dengan hasil kultur darah positif didapatkan $9(69,2 \%)$ berjenis kelamin laki-laki dan $4(30,8 \%)$ berjenis kelamin perempuan. Pada 13 pasien sepsis neonatal dengan hasil kultur darah negatif didapatkan $8(61,5 \%)$ berjenis kelamin lakilaki dan $5(38,5 \%)$ berjenis kelamin perempuan. (Tabel 1)

Bakteri penyebab sepsis neonatal terdiri dari 11 bakteri Gram Positif (84,6\%) dan 2 bakteri Gram Negatif (15,4\%). Pola kuman penyebab sepsis neonatal didominasi Staphylococcus $s p$. $(84,6 \%)$ yang terdiri dari Coagulase-negative Staphylococcus/CoNS $(81,8 \%)$ dan Staphylococcus aureus $(18,2 \%)\}$, Salmonella spp (7,7\%) dan Klebsiella pneumoniae (7,7\%). Secara keseluruhan, bakteri Coagulase-negative Staphylococci (69,2\%) merupakan penyebab terbanyak bakteremia pada penelitian ini. (Tabel 2).

Hasil uji sensitivitas untuk melihat resistensi bakteri Staphylococci sp terhadap Cefoxitin didapatkan 5 (83,3\%) Methicillin-resistant Staphylococci (MRS) dan 1 (16,7\%) Meticillinresistant Staphylococcus aureus/MRSA (Tabel 3).

Hasil pemeriksaan kadar antitrombin III pada pasien sepsis neonatal kultur darah positif $(73,23$ $\pm 21,62)$ lebih tinggi daripada sepsis dengan kultur darah negatif $(65,63 \pm 20,81)$. Akan tetapi, tidak ditemukan perbedaan yang signifikan pada uji $t$ independen antara kadar AT III pada pasien sepsis neonatal kultur darah positif dan kultur darah negatif dengan nilai $\mathrm{p}=0,370(\mathrm{p}>0,05)$.

\section{PEMBAHASAN}

Pada penelitian ini, dari 26 neonatus sepsis neonatal didapatkan 17 laki-laki $(65,4 \%)$ dan 9 perempuan $(34,6 \%)$ dengan rasio laki-laki dan perempuan $1,8: 1$. Hal ini sesuai dengan penelitian Shrestha et al (2013) rasio laki-laki dan perempuan 1,5:1. Jumlah laki-laki yang lebih besar pada septikemia neonatal mungkin terkait dengan faktor gen imunoregulatori $\mathrm{X}$-linked yang berkontribusi terhadap kerentanan host terhadap infeksi pada laki-laki. Shrestha et al (2013) juga menyatakan bahwa neonatus laki-laki secara signifikan lebih banyak mengalami sepsis neonatal dengan kultur darah positif, yang juga ditemukan pada penelitian ini. ${ }^{11}$

Pada penelitian ini ditemukan pola kuman penyebab sepsis neonatal sebagai berikut, Staphylococcus sp. $\quad(84,6 \%) \quad$ CoNS $(81,8 \%)$, Staphylococcus aureus $(18,2 \%)\}$, Salmonella spp $(7,7 \%)$ dan Klebsiella pneumoniae ssp pneumoniae $(7,7 \%)$. Hasil ini sesuai dengan penelitian sebelumnya di RSUP H. Adam Malik Medan oleh Sianturi, P. et al. (2012) Jenis kuman yang paling banyak dijumpai adalah Staphylococcus sp. ${ }^{4}$

Bakteri CoNS $(69,2 \%)$ merupakan penyebab 
terbanyak bakteremia pada penelitian ini. Hal ini sesuai dengan penelitian Gheibi et al (2008) CoNS merupakan penyebab paling umum dari sepsis neonatal, baik early onset sepsis $(48,8 \%)$ dan late onset sepsis $(69,8 \%)$ diikuti oleh Klebsiella, E. coli dan Staphylococcus aureus. ${ }^{12}$

CoNS, yang merupakan anggota flora normal kulit manusia, telah muncul sebagai patogen nosokomial penting selama beberapa dekade terakhir. CoNS, terutama Staphylococcus epidermidis dan Staphylococcus haemolyticus, dapat menyebabkan infeksi berat pada bayi baru lahir, termasuk meningitis atau bakteremia, namun di sisi lain, mereka lazim di lingkungan rumah sakit dan di tangan petugas kesehatan. ${ }^{13}$

Pada penelitian ini, pola sensitivitas bakteri Staphylococci terhadap Cefoxitin untuk melihat resistensi didapatkan MRSA berkontribusi 16,7\% dan Staphylococcus epidermidis serta Staphylococcus haemolyticus sebesar 83,3\%. Resistensi meticillin pada Staphylococci diakibatkan adanya penicillin binding protein 2a (PBP2a), yang dikodekan oleh gen mecA dan terletak pada Staphylococcal cassette chromosome mec (SCCmec). ${ }^{14,15}$

Methicillin-resistant Staphylococci resisten terhadap semua penicillin lainnya, carbapenem, cephem dan $\beta$-lactam/kombinasi $\beta$-lactamase inhibitor. Akibatnya, antibiotik ini tidak boleh digunakan untuk mengobati infeksi Methicillinresistant Staphylococci. ${ }^{16}$ Resistensi terhadap meticillin pada CoNS sangat umum di antara isolat yang dari individu yang telah dirawat di rumah sakit. Untuk alasan ini, vancomycin biasanya merupakan drug of choice untuk infeksi oleh MRS. ${ }^{17,18}$

MRSA adalah strain Staphylococcus aureus yang telah berkembang, melalui transfer gen horizontal dan seleksi alam, multiresistensi terhadap antibiotik $\beta$-lactam, yang meliputi penicillin (metisillin, dicloksasillin, nafsillin, oksasillin, dll) dan cefalosporin. Evolusi resistensi tersebut tidak menyebabkan organisme menjadi lebih virulen secara intrinsik daripada strain Staphylococcus aureus yang tidak memiliki resistensi antibiotik, tetapi resistensi membuat infeksi MRSA lebih sulit diobati dengan jenis antibiotik standar dan dengan demikian lebih berbahaya. ${ }^{19}$

Menurut Beshlawy et al (2010) Koagulasi dan inhibitor faktor koagulasi secara progresif disintesis oleh janin yang dimulai terutama setelah 34 minggu kehamilan dan jam-jam awal setelah dilahirkan, untuk menjamin adanya keseimbangan hemostatis yang cukup saat kelahiran. Oleh sebab itu penelitian ini hanya melibatkan neonatus yang lahir pada usia gestasi 34 minggu atau lebih. ${ }^{5}$

AT III merupakan antikoagulan alami penting yang menghambat koagulasi dan inflamasi yang overactivated selama sepsis melalui jalur multifaktorial. Namun, aktivitasnya menurun secara signifikan pada sepsis terkait DIC. Mekanisme yang bertanggung jawab terhadap penurunan kadar AT III selama sepsis, antara lain: konsumsi AT III selama koagulasi teraktivasi, penurunan sintesis AT III di liver, degradasi AT III oleh elastase neutrofil, dan kebocoran AT III ke ruang ekstravaskular. Kadar aktivitas AT III yang berkurang menyebabkan penurunan kemampuan untuk menginaktivasi trombin, yang menyebabkan akselerasi sistem koagulasi lebih lanjut. Sebelumnya dilaporkan bahwa kadar aktivitas AT III sekitar $80 \%$ kadar normal pada pasien septik tanpa disfungsi organ, menurun menjadi sekitar $60 \%$ pada pasien dengan sepsis berat, dan $40 \%$ pada pasien dengan DIC. AT III adalah diskriminator yang sangat baik terhadap tingkat keparahan sepsis. Baru-baru ini, Choi dkk melaporkan korelasi yang signifikan antara AT III dan skor DIC pada pasien sepsis, yang menunjukkan bahwa AT III adalah indikator yang baik untuk tingkat keparahan DIC. ${ }^{20}$

Pada penelitian ini tidak terdapat perbedaan yang signifikan kadar antitrombin III pada pasien sepsis neonatal kultur darah positif dan kultur darah negatif, dimana kadar antitrombin III pada pasien sepsis neonatal kultur darah positif $(73,23$ $\pm 21,62)$ dan kultur darah negatif $(65,63 \pm 20,81)$ dengan nilai $\mathrm{p}=0,370(\mathrm{p}>0,05)$. Pada penelitian ini didapatkan kadar AT III pasien sepsis neonatal yang masih dalam batas normal bila dibandingkan dengan nilai referensi kadar AT III berdasarkan umur, baik pada pasien sepsis neonatal dengan hasil kultur darah positif dan hasil kultur darah negatif. Hal ini mungkin disebabkan karena pada penelitian ini hanya diikuti oleh pasien sepsis neonatal tanpa komplikasi.

\section{SIMPULAN DAN SARAN}

Pada penelitian ini tidak terdapat perbedaan yang signifikan pada kadar antitrombin III pada pasien sepsis neonatal kultur darah positif dan kultur darah negatif. Diperlukan penelitian lanjutan untuk melihat keluaran (outcome) mortalitas dari pasien sepsis neonatal hasil kultur darah positif dan kultur darah negatif.

\section{DAFTAR PUSTAKA}

1. Utomo M.T. Risk Factors of Neonatal Sepsis: A Preliminary Study in Dr. Soetomo Hospital. Indones J Trop Infect Dis. 2010;1(1):23.

2. Gomella T.., Cunningham M.., Eyal F.. Neonatology Management, Procedures, On-Call Problems, Diseases, and Drugs. 7th ed. New York: Mc Graw Hill Education; 2013.

3. Depkes RI. Penatalaksanaan Sepsis Neonatorum. Jakarta; 2007. 
4. Sianturi P., Hasibuan B.S., Lubis B.M., Azlin E., Tjipta G.D. Profil Sepsis Neonatus di Unit Perawatan Neonatus RSUP H Adam Malik Medan Tahun 2008 - 2010. Sari Pediatr. 2016;14(2):67-72.

5. Beshlawy A. El, Alaraby I., Abou Hussein H., Abou-Elew H.H., Mohamed Abdel Kader M.S.E. Study of protein C, protein S, and antithrombin III in newborns with sepsis. Pediatr Crit Care Med. 2010;11(1):52-9.

6. Rodgers G.M. Role of antithrombin concentrate in treatment of hereditary antithrombin deficiency. An update. Thromb Haemost. 2009;101(5):806-12.

7. Ersoy B., Nehir H., Altinoz S., Yilmaz O., Dundar P.E., Aydogan A. Prognostic value of initial antithrombin levels in neonatal sepsis. Indian Pediatr. 2007;44(8):581-4.

8. Maclean P.S., Tait R.C. Hereditary and Acquired Antithrombin Deficiency. Drugs. 2007;67(10):1429-40.

9. Muntaha S.T., Akram W., Hassan F. Prognostic Value of Anti-Thrombin III Level in Neonatal Sepsis [Internet]. Vol. 20, Journal of Rawalpindi Medical College (JRMC). 2016.

10. Andropoulus D.B. Pediatric Normal Laboratory Values. In: Gregory G., Andropoulus DB, editors. Gregory's Pediatric Anesthesia. Houston: Blackwell Publishing Ltd; 2012. p. 1300-14.

11. Shrestha S., Dongol Singh S., Shrestha N.C., Shrestha R.P.B., Madhup S.K. Comparision of clinical and laboratory parameters in culture proven and unproven early onset sepsis in NICU. Kathmandu Univ Med J (KUMJ). 11(44):310-4.

12. Gheibi S., Gastroenterologist P., Fakoor Z., Karamyyar M., Infectious Diseases Specialist P., Khashabi J., et al. Coagulase Negative Staphylococcus; the Most Common Cause of Neonatal Septicemia in Urmia, Iran Coagulase Negative Staphylococcus; the Most Common Cause of Neonatal Sepsis; Sh Gheibi, et al [Internet]. Vol. 18, Original Article Iran J Pediatr Sep. 2008.

13. Brzychczy-Wloch M., Wojkowska-Mach J., Gadzinowski J., Opala T., Szumala-Kakol A., Kornacka A., et al. Outbreak
Intervention for Bloodstream Infections Caused by Methicillin Resistant Coagulase-Negative Staphylococci in Neonatal Intensive Care Unit. Clin Microbiol Open Access. 2012;04(02):1-7.

14. Garza-gonzález E., Morfín-otero R., Llaca-díaz j. M., Rodriguez-noriega E. Staphylococcal cassette chromosome mec (SCC mec) in methicillin-resistant coagulase-negative staphylococci. A review and the experience in a tertiarycare setting. Epidemiol Infect. 2010;138(05):645.

15. Zong Z., Peng C., Lü X. Diversity of SCCmec elements in methicillin-resistant coagulase-negative staphylococci clinical isolates. PLoS One. 2011;6(5):e20191.

16. Koksal F., Yasar H., Samasti M. Antibiotic resistance patterns of coagulase-negative staphylococcus strains isolated from blood cultures of septicemic patients in Turkey. Microbiol Res. 2009;164(4):404-10.

17. Fuchs A., Bielicki J., Mathur S., Sharland M., Van Den Anker J.N. Antibiotic Use for Sepsis in Neonates and Children: 2016 Evidence Update WHO-Reviews [Internet].

18. Paiva R.M., Mombach Pinheiro Machado A.B., Zavascki A.P., Barth A.L. Vancomycin MIC for Methicillin-Resistant Coagulase-Negative Staphylococcus Isolates: Evaluation of the Broth Microdilution and Etest Methods. J Clin Microbiol. 2010;48(12):4652-4.

19. Rajesh S., Divya B., Neelaveni D., Subathra N. Incidence of Methicillin Resistant Staphylococcus aureus Infection in Neonatal Septicemia in a Tertiary Care Hospital. IntJCurrMicrobiolAppSci. 2017;6(5):2874-81.

20. Iba T., Saitoh D. Efficacy of antithrombin in preclinical and clinical applications for sepsis-associated disseminated intravascular coagulation. J intensive care. 2014;2(1):66.

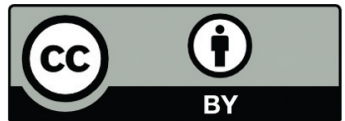

This work is licensed under a Creative Commons Attribution 